\title{
Pengaruh pemberian jus jeruk manis (citrus sinensis.) terhadap nilai VO2max atlet sepak bola di Gendut Dony Training Camp (GDTC) Salatiga
}

\author{
Sofia Arum Andani ${ }^{1}$, Nurmasari Widyastuti ${ }^{1}$
}

\begin{abstract}
Background : Endurance is the ability of the body to perform activities or work for a long time without experiencing fatigue. Based on using of energy systems, endurance is divided into aerobic and anaerobic. Aerobic endurance is measured using $\mathrm{VO}_{2}$ max value. Aerobic endurance is supported by the availability of carbohydrates and fats. Intake of carbohydrates as much as 30-60 grams/hour can maintain glucose levels and maintain the level of burning carbohydrates in the body, so it can improve the endurance about 30-60 minutes. Carbohydrate content in $300 \mathrm{ml}$ of sweet orange juice is 54,9 grams that can be used to increase endurance atheletes.

Objective : The purpose of this study was to analyze the effect of orange juice on $\mathrm{VO}_{2}$ max value in football athletes.

Method: This study was in the field of experimental design with post test only with controlled group design. Subject for these study were tweenty-one football athletes which are match with inclusion criteria in Gendut Dony Training Camp (GDTC) Salatiga. The Subject has given $300 \mathrm{ml}$ orange juice and $300 \mathrm{ml}$ placebo 30 minutes before test. VO $\mathrm{O}_{2}$ max value was measured by using Balke running test. All datas were analyzed by Independent Sample T-tes.

Result : Subject characteristic includes age, weight, height, body mass index (BMI), and total food intake were not showing significant difference $(p<0,05)$, therefore subject were categorized as homogen. Significant difference was showed in average of $\mathrm{VO}_{2}$ max value between the treatment group $(43,67 \pm 2,26)$ and control group $(39,33 \pm 4,39)$.

Conclusion : Consumption of orange juice 30 minutes before exercising shows a significant impact to increase the VO ${ }_{2}$ max value.
\end{abstract}

Keywords : orange juice, $\mathrm{VO}_{2} \max$, Balke running test

\begin{abstract}
ABSTRAK
Latar belakang : Daya tahan adalah kemampuan kondisi tubuh untuk melakukan aktivitas atau kerja dalam waktu yang lama tanpa mengalami kelelahan. Berdasarkan penggunaan sistem energi, ketahanan dibedakan menjadi ketahanan aerob dan anaerob. Pengukuran ketahanan aerobik dilakukan dengan cara mengukur volume oksigen maksimal (VO $\mathrm{O}_{2}$ max). Daya tahan aerobik didukung dengan ketersediaan karbohidrat dan lemak. Pemberian karbohidrat sebesar 30-60 gram/jam dapat mempertahankan level glukosa dan menjaga tingkat pembakaran karbohidrat di dalam tubuh, sehingga dapat meningkatkan ketahanan sekitar 30-60 menit. Kandungan karbohidrat pada 300 ml jus jeruk manis sebesar 54,9 gram yang dapat digunakan untuk meningkatan daya tahan atlet.

Tujuan : Penelitian ini bertujuan mengetahui pengaruh pemberian jus jus jeruk manis terhadap nilai VO ${ }_{2}$ max pada atlet sepak bola.

Metode : Penelitian ini merupakan penelitian eksperimental dengan rancangan post test only with controlled group design. Jumlah subjek penelitian adalah 21 atlet sepak bola yang memenuhi kriteria inklusi di Gendut Dony Training Camp (GDTC) Salatiga. Subjek penelitian menerima intervensi pemberian $300 \mathrm{ml}$ jus jeruk manis dan $300 \mathrm{ml}$ placebo 30 menit sebelum dilakukan tes. Nilai $\mathrm{VO}_{2}$ max diukur menggunakan tes lari 15 menit Balke. Data nilai $\mathrm{VO}_{2}$ max dianalisis menggunakan uji Independet Sampel T-tes.

Hasil : Karakteristik subjek meliputi umur, berat badan, tinggi badan, IMT, serta total energi dan karbohidrat pada kedua kelompok tidak menunjukkan perbedaan $(p>0,05)$ sehingga subjek dikatakan homogen. Terdapat perbedaan rerata nilai $\mathrm{VO}_{2}$ max yang signifikan antara kelompok perlakuan $(43,67 \pm 2,26)$ dengan kelompok kontrol $(39,33 \pm 4,39)$.

Simpulan : Pemberian jus jeruk manis 30 menit sebelum olahraga berpengaruh secara bermakna untuk meningkatkan nilai $\mathrm{VO}_{2} \max$.
\end{abstract}

Kata kunci : jus jeruk manis, $\mathrm{VO}_{2}$ max, tes lari 15 menit Balke

\section{PENDAHULUAN}

Daya tahan merupakan salah satu komponen utama dalam setiap cabang olahraga yang digunakan sebagai parameter untuk mengetahui tingkat kebugaran

\footnotetext{
1. Departemen Ilmu Gizi, Fakultas Kedokteran, Universitas Diponegoro, Jl. Prof. Sudarto SH, Tembalang, Semarang (email korespondensi : widyastutianlene@gmail.com)
}

jasmani seorang atlet. Daya tahan adalah kemampuan kondisi tubuh untuk melakukan aktivitas atau kerja dalam waktu yang lama tanpa mengalami kelelahan. ${ }^{1}$ Daya tahan juga dapat diartikan sebagai kemampuan otot untuk berkontraksi secara terus menerus dalam waktu yang relatif lama dengan beban tertentu. ${ }^{2}$ Berdasarkan penggunaan sistem energi, ketahanan dibedakan menjadi ketahanan aerob dan anaerob. ${ }^{3}$ Ketahanan aerob adalah kemampuan seseorang untuk 
mengatasi beban latihan dalam jangka waktu lebih dari tiga menit secara terus menerus.

Pengukuran ketahanan aerobik dapat dilakukan dengan cara mengukur volume oksigen maksimal $\left(\mathrm{VO}_{2} \max \right)$. $\mathrm{VO} 2 \mathrm{max}$ atau yang disebut volume oksigen maksimal dapat didefinisikan sebagai kapasitas maksimal tubuh dalam mengambil, mentranspor, dan menggunakan oksigen selama latihan. ${ }^{4}$ Nilai VO2max menggambarkan nilai transport oksigen maksimal dari otot ke mitokondria untuk memproduksi energi. ${ }^{5,6}$ Atlet dengan daya tahan yang tinggi memiliki nilai $\mathrm{VO}_{2}$ max yang tinggi dan dapat melakukan latihan fisik yang lebih kuat dibandingkan atlet yang memiliki daya tahan rendah. ${ }^{3}$ Nilai VO2max sebagai parameter nilai daya tahan (endurance) dapat digunakan untuk melihat kelelahan aerob. Daya tahan berbanding terbalik dengan kelelahan. Artinya, atlet yang mudah mengalami kelelahan memiliki daya tahan yang buruk dan nilai VO2max yang rendah.,

Salah satu cara untuk mengukur nilai VO2max adalah menggunakan tes lari 15 menit Balke. ${ }^{7}$ Tes ini cocok untuk mengukur daya tahan dan kebugaran untuk olahraga ketahanan dan kelompok seperti sepakbola. Sepak bola merupakan salah satu cabang olahraga dengan kombinasi aerobik - anaerobik. Pertandingan sepak bola berlangsung selama $2 \times 45$ menit, sehingga membutuhkan kondisi fisik yang prima serta daya tahan yang kuat. ${ }^{8}$ Atlet yang tidak memiliki kondisi fisik yang prima dan daya tahan kuat berisiko mengalami kelelahan pada saat pertandingan maupun saat latihan, sehingga dapat menurunkan suatu prestasi atlet. $^{9}$

Daya tahan aerobik didukung dengan ketersediaan karbohidrat dan lemak. Berdasarkan penlitian, karbohidrat memiliki hubungan dengan peningkatan nilai $\mathrm{VO}_{2} \max$ karena karbohidrat merupakan sumber energi utama untuk seorang atlet dalam melakukan olahraga. Karbohidrat yang terdapat dalam tubuh berupa glukosa dan glikogen yang disimpan di dalam otot dan hati. Otot menggunakan glukosa yang disimpan dalam bentuk glikogen di otot tersebut sebagai bahan bakar yang digunakan ketika bekerja dan pemberian karbohidrat bertujuan untuk mengisi kembali glikogen otot dan hati yang telah digunakan untuk kontraksi otot. ${ }^{10}$ Atlet yang mempunyai simpanan glikogen sedikit akan merasa cepat lelah, dan kurang berprestasi. ${ }^{11}$ Oleh karena itu, karbohidrat memiliki peranan yang penting untuk penghasil sumber energi yang dibutuhkan saat melakukan olahraga. Lemak juga penting sebagai sumber tenaga, meskipun bukan sumber tenaga utama dalam olahraga dengan intensitas ringan sampai berat. Intensitas dan durasi olahraga menentukan oksidadi lemak. Otot akan menggunakan asam lemak sebagai energi apabila glukosa darah menurun. ${ }^{12}$
Selain karbohidrat dan lemak, kalium juga berperan dalam ketahanan aerob. Kalium berperan aktif dalam metabolisme glikogen dan glukosa, mengubah glukosa menjadi glikogen yang disimpan dalam hati sebagai energi. ${ }^{13}$ Kalium berfungsi untuk kontraksi otot bersama natrium, magnesium dan kalsium. Kalium merupakan elektrolit yang penting bagi tubuh karena berfungsi dalam untuk mengubah impuls saraf ke otot pada kontraksi otot dan menjaga tekanan darah tetap normal. ${ }^{14}$ Kekurangan kalium dapat mengakibatkan kelemahan otot sehingga akan menimbulkan kelelahan otot. Selama berolahraga, kalium dapat diperoleh dari makanan olahraga, seperti mengonsumsi pisang dan jeruk. ${ }^{15}$

Buah jeruk (Citrus sinensis) merupakan buah yang mengandung karbohidrat sederhana dan karbohidrat kompleks. Karbohidrat sederhana pada buah jeruk yaitu fruktosa, glukosa dan sukrosa yang dapat menyediakan energi secara cepat. ${ }^{16}$ Berdasarkan uji laboratorium, kandungan karbohidrat pada $300 \mathrm{ml}$ jus jeruk manis sebesar 54,9 gram. Jumlah tersebut dapat digunakan untuk meningkatan daya tahan atlet saat berlatih maupun pertandingan. Hal tersebut sesuai dengan penelitian sebelumnya bahwa jumlah karbohidrat yang diperlukan untuk meningkatkan ketahanan yaitu sebesar 30-60 gram/jam. Jumlah tersebut dapat mempertahankan level glukosa dan menjaga tingkat pembakaran karbohidrat di dalam tubuh, sehingga dapat meningkatkan ketahanan sekitar 30-60 menit. ${ }^{8}$ Selain itu, buah jeruk memiliki indeks glikemik rendah yang apabila dikonsumsi 30 menit sebelum olahraga dapat menstabilkan tingkat energi dan dapat memberikan kekutan selama 60 menit berolahraga. ${ }^{17}$

Berdasarkan uji laboratorium, kandungan gizi pada $300 \mathrm{ml}$ jus jeruk manis yaitu 264,54 gram air, 0,45 gram abu, 1,92 gram protein, 1,17 gram lemak, 4,47 gram serat dan 237,4 mg kalium. Kandungan kalium pada jus jeruk $(237,4 \mathrm{mg} / 300 \mathrm{ml})$ lebih tinggi dibandingkan jus buah lain seperti apel $(187,2$ $\mathrm{mg} / 300 \mathrm{ml})$, pear $(208,8 \mathrm{mg} / 300 \mathrm{ml})$ dan anggur $(64,8$ $\mathrm{mg} / 300 \mathrm{ml}) .{ }^{18}$ Buah jeruk mengandung kalium untuk membantu menjaga keseimbangan cairan dan asam. Selain itu, buah jeruk merupakan sumber vitamin C yang berfungsi sebagai antioksidan, membantu untuk mencegah kerusakan oksidatif yang dapat terjadi selama latihan endurance. Buah jeruk juga mengandung vitamin B kompleks antara lain thiamin, niacin, vitamin B6, riboflavin, dan asam pantotenat yang terlibat dalam jalur produksi energi dan dibutuhkan dalam jumlah yang lebih tinggi untuk ketahanan atlet. ${ }^{19}$ Jeruk manis memiliki kandungan karbohidrat dan kalium yang lebih tinggi dibandingkan dengan jeruk lemon, mandarin, grapefruit, dan jeruk limau. ${ }^{6,7}$ Jeruk manis yang digunakan dalam penelitian ini adalah jeruk manis pacitan yang merpakan jeruk 
lokal asli Indonesia. Jeruk ini memiliki rasa paling manis bahkan sebelum matang serta memiliki kandungan air yang tinggi. ${ }^{20}$

\section{BAHAN DAN METODE}

Penelitian ini merupakan penelitian eksperimen dengan rancangan post test only with control group design. Variabel terkait (dependent) dalam penelitian ini adalah nilai $\mathrm{VO}_{2}$ max. Variabel bebas (independent) adalah pemberian jus jeruk manis dengan $300 \mathrm{ml}$.

Perhitungan subjek pada penelitian ini menggunakan rumus slovin sehingga dibutuhkan 21 subjek. Subjek dibagi menjadi dua kelompok perlakuan yaitu kelompok kontrol (300 ml placebo yang berupa air dengan penambahan pewarna makanan) sebanyak 10 atlet dan kelompok perlakuan (jus jeruk manis 300 $\mathrm{ml}$ ) sebanyak 11 atlet menggunakan teknik simple random sampling. Subjek penelitian ditentukan dengan menggunakan dengan kriteria inklusi sebagai berikut atlet merupakan atlet sepak bola laki-laki usia 15-18 tahun; tidak mengonsumsi suplemen, vitamin dan mineral dosis tinggi, herbal dan obat yang berkaitan dengan reaksi inflamasi dan fungsi imun seperti ibuprofen, aspirin, asam mefenamat, parasetamol, antalgin atau metampiron, hidrokortison, deksametason, prednison selama penelitian berlangsung; tidak dalam perawatan dokter atau pascaoperasi 6 bulan sebelum penelitian dan bersedia mengikuti penelitian melalui persetujuan informed consent. Subjek dinyatakan keluar dari penelitian apabila mengalami cidera pada saat penelitian berlangsung, merokok, mengonsumsi suplemen, vitamin dan mineral dosis tinggi, herbal dan obat yang berkaitan dengan reaksi inflamasi dan fungsi imun seperti ibuprofen, aspirin, asam mefenamat, parasetamol, antalgin atau metampiron, hidrokortison, deksametason, prednison selama penelitian berlangsung dan menyatakan keluar dari penelitian.

Pemberian jus jeruk yaitu jenis jus jeruk manis dilakukan 30 menit sebelum dilaksanakan tes lari 15 menit Balke. Atlet yang termasuk kelompok perlakuan diberikan waktu sebanyak 3 menit untuk menghabiskan jus jeruk manis yang diberikan. Prosedur tes dari penelitian ini adalah subjek tidak boleh merokok pada saat dilakukan tes, makan utama 4 jam sebelum tes, kelompok perlakuan mendapatkan $300 \mathrm{ml}$ jus jeruk manis sedangkan kelompok kontrol mendapatkan placebo $300 \mathrm{ml} 30$ menit sebelum tes dilakukan, dan subjek hanya diperbolehkan untuk minum air selama dilakukan tes.

Subjek melakukan tes lari 15 menit Balke. Prosedur pelaksanaan tes Balke adalah atlet berdiri digaris start dan bersikap untuk berlari secepat cepatnya selama 15 menit. Bersamaan dengan aba-aba dari pelatih, stopwatch dihidupkan dan atlet mulai berlari selama 15 menit sampai ada aba-aba untuk berhenti (bunyi peluit sebgaai tanda tes sudah berakhir). Bersamaan dengan itu stopwatch dimatikan. Kemudian, petugas mengukur jarak yang ditempuh atlet dan mencatatnya. ${ }^{18}$

Pencatatan asupan makan 24 jam sebelum dilakukan tes lari 15 menit Balke dengan metode food recall 24 jam, kemudian data asupan makan subjek dianalisis menggunakan program nutrisurvey. Nilai $\mathrm{VO}_{2} \max$ pada atlet didapatkan dari hasil tes lari 15 menit Balke dengan menganalisis jarak yang ditempuh atlet. Rumus $\mathrm{VO}_{2}$ max untuk lari 15 menit Balke yaitu:

$\mathrm{VO}_{2} \max =\left(\frac{x \text { meter }}{15}-133\right) x 0,172+33,3=\cdots \frac{\frac{\mathrm{ml}}{\mathrm{kgBB}}}{\text { menit }}$

Data nilai $\mathrm{VO}_{2} \max$ yang diperoleh diuji normalitas datanya dengan uji Shapiro Wilk karena sampel kurang dari 50. Perbedaan rerata nilai $\mathrm{VO}_{2} \max$ antara kelompok kontrol dengan perlakuan diuji menggunakan Independent sampel T-test. Perbedaan dianggap bermakna apabila $\mathrm{p}<0,05 .^{19}$

\section{HASIL}

\section{Karakteristik Subjek}

Hasil uji beda dengan uji Mann-Whitney menunjukkan bahwa tidak terdapat perbedaan umur, berat badan, tinggi badan, IMT dan rerata total energi, karbohidrat serta kalium antara kedua kelompok $(\mathrm{p}>0,05)$.

Tabel 1. Karakteristik Subjek Penelitian

\begin{tabular}{|c|c|c|c|}
\hline \multirow[t]{2}{*}{ Variabel } & Kontrol $(\mathrm{n}=10)$ & Perlakuan $300 \mathrm{ml}(\mathrm{n}=11)$ & \multirow[t]{2}{*}{$\mathbf{p}^{*}$} \\
\hline & Mean \pm SD & Mean \pm SD & \\
\hline Umur (tahun) & $16,20 \pm 1,135$ & $16,55 \pm 0,934$ & 0,38 \\
\hline Berat badan $(\mathrm{kg})$ & $61,64 \pm 7,55$ & $61,24 \pm 1,59$ & 0,778 \\
\hline Tinggi badan $(\mathrm{m})$ & $1,67 \pm 0,04$ & $1,65 \pm 0,06$ & 0,944 \\
\hline Indeks Massa Tubuh $\left(\mathrm{kg} / \mathrm{m}^{2}\right)$ & $21,99 \pm 2,24$ & $22,32 \pm 3,84$ & 1,00 \\
\hline Total Energi (kkal) & $2443,6 \pm 291,2$ & $2691,9 \pm 557,8$ & 0,36 \\
\hline Total Karbohidrat (gram) & $350,29 \pm 42,89$ & $367,22 \pm 52,42$ & 0,526 \\
\hline Total Kalium (mg) & $1437,43 \pm 199,3$ & $1420,34 \pm 273,57$ & 0,888 \\
\hline
\end{tabular}

*berdasarkan uji Mann-Whitney 
Tabel 2. Nilai $\mathrm{VO}_{2} \mathrm{max}$

\begin{tabular}{|c|c|c|c|c|c|c|c|}
\hline \multirow[t]{2}{*}{ Variabel } & \multicolumn{3}{|c|}{$\begin{array}{c}\text { Kontrol } \\
(n=10)\end{array}$} & \multicolumn{3}{|c|}{$\begin{array}{c}\text { Perlakuan } 300 \mathrm{ml} \\
(\mathrm{n}=11)\end{array}$} & \multirow[t]{2}{*}{$\mathbf{p}^{*}$} \\
\hline & Mean \pm SD & Min & $\operatorname{Max}$ & Mean \pm SD & Min & $\operatorname{Max}$ & \\
\hline $\mathrm{VO}_{2} \max$ & $39,33 \pm 4,39$ & 32,16 & 46,36 & $43,67 \pm 2,27$ & 40,08 & 46,16 & 0,009 \\
\hline
\end{tabular}

*berdasarkan uji Independent Sampel T-test

\section{Pengaruh Pemberian Jus Jeruk Manis terhadap Nilai $\mathrm{VO}_{2}$ max}

Tabel 2 menunjukkan bahwa terdapat perbedaan rerata nilai $\mathrm{VO}_{2}$ max pada kelompok kontrol dan kelompok perlakuan. Rerata nilai $\mathrm{VO}_{2} \max$ pada kelompok kontrol lebih rendah daripada kelompok perlakuan. Pada tabel tersebut juga menunjukkan bahwa nilai minimun pada kelompok kontrol adalah 32,16 dan pada kelompok perlakuan yang diberi jus jeruk manis $300 \mathrm{ml}$ adalah 40,08. Sedangkan, nilai maksimum pada kelompok kontrol adalah 46,36 dan pada kelompok perlakuan adalah 46,16.

\section{PEMBAHASAN}

Sepak bola merupakan salah satu olahraga yang membutuhkan kekuatan otot dan daya tahan yang tinggi (endurance) untuk berlari cepat, menendang bola, melempar bola, mempertahankan keseimbangan tubuh dan mencegah terjatuh saat benturan dengan pemain lawan. ${ }^{24}$ Daya tahan adalah kemampuan otot untuk berkontraksi secara terus menerus dalam waktu yang relatif lama dengan beban tertentu. ${ }^{2}$ Berdasarkan penggunaan sistem energi, ketahanan dibedakan menjadi ketahanan aerob dan anaerob. ${ }^{3}$ Pengukuran ketahanan aerobik dapat dilakukan dengan cara mengukur volume oksigen maksimal $\left(\mathrm{VO}_{2} \mathrm{max}\right)$. Volume oksigen maksimal $\left(\mathrm{VO}_{2} \mathrm{max}\right)$ didefinisikan sebagai kapasitas maksimal tubuh dalam mengambil, mentranspor, dan menggunakan oksigen selama latihan. ${ }^{6} \quad \mathrm{VO}_{2} \max$ atau tenaga aerobik maksimum adalah kecepatan terbesar dimana seseorang menggunakan oksigen selama berolahraga. VO2max menunjukkan volume oksigen maksimal yang dapat dikonsumsi oleh jaringan selama melakukan aktivitas per menit. ${ }^{21}$

Selama latihan fisik, terjadi peningkatan kebutuhan oksigen oleh otot yang sedang bekerja. Kebutuhan oksigen ini didapatkan dari ventilasi dan pertukaran oksigen dalam paru-paru. Ventilasi merupakan proses mekanik untuk memasukkan atau mengeluarkan udara dari dalam paru-paru. Proses ini berlanjut dengan pertukaran oksigen dalam alveoli paru dengan cara difusi. Oksigen yang terdifusi masuk dalam kapiler paru untuk dan selanjutnya diedarkan melalui pembuluh darah ke seluruh tubuh. Dalam memasok kebutuhan oksigen yang kuat, dibutuhkan paru-paru yang berfungsi dengan baik, termasuk juga kapiler dan pembuluh pulmonalnya. ${ }^{22}$ Orang yang mempunyai daya tahan yang tinggi karena melakukan olahraga, ternyata memiliki kemampuan paru-paru untuk menampung 1,5 lebih banyak udara daripada orang biasa. Lebih tinggi kebugaran jasmani seseorang, maka lebih banyak oksigen yang dapat diproses oleh tubuh kita.

Berdasarkan hasil penelitian menunjukkan bahwa kelompok subjek yang diberikan $300 \mathrm{ml}$ jus jeruk manis memiliki rata-rata nilai $\mathrm{VO}_{2} \max$ lebih tinggi dibandingkan kelompok subjek yang diberi 300 $\mathrm{ml}$ placebo. Berdasarkan hasil penelitian tersebut diketahui bahwa jus jeruk manis terbukti memiliki pengaruh terhadap nilai $\mathrm{VO}_{2} \max$. Hal tersebut sesuai dengan hipotesis dari penelitian ini. Subjek yang memiliki nilai $\mathrm{VO}_{2} \max$ tinggi berarti memiliki kebugaran jasmani yang baik, sedangkan yang memiliki nilai $\mathrm{VO}_{2}$ max rendah memiliki kebugaran jasmani yang buruk.

VO2max atau ketahanan aerobik bukan hanya sebagai parameter metabolisme melainkan ukuran handal dalam kesegaran jasmani. ${ }^{23}$ Daya tahan aerobik bekerja dengan bantuan oksigen dan asupan makan dalam tubuh. Setiap sel membutuhkan oksigen untuk mengubah energi makanan menjadi ATP (Adenosine Triphosphate) yang dipakai untuk kerja tiap sel. Sel otot yang berkontraksi membutuhkan banyak ATP sehingga sel otot membutuhkan banyak oksigen dan menghasilkan $\mathrm{CO}_{2}$. Pada saat berolahraga, kedua simpanan energi tubuh yaitu simpanan karbohidrat (glukosa darah, glikogen otot dan hati) dan simpanan lemak yang berbentuk trigliserida akan memberikan kontribusi terhadap laju produksi energi secara aerobik di dalam tubuh.

Karbohidrat merupakan sumber energi utama untuk seorang atlet dalam melakukan olahraga. Semua jenis karbohidrat tersebut akan terkonversi menjadi glukosa di dalam tubuh. Glukosa yang terbentuk kemudian dapat tersimpan sebagai cadangan energi sebagai glikogen di dalam hati $(18 \%-22 \%)$ dan otot $(80 \%)$ serta dapat tersimpan di dalam aliran darah sebagai glukosa darah atau dapat juga dibawa ke dalam sel-sel tubuh yang membutuhkan. ${ }^{11,24}$ Glukosa yang berasal dari glukosa darah dan glikogen akan mengalami proses glikolisis yang menghasilkan molekul ATP dan asam piruvat. Asam piruvat yang dihasilkan akan diubah menjadi asetil KoA di dalam mitokondria dengan bantuan oksigen. Upaya untuk 
memenuhi kebutuhan energi bagi sel-sel tubuh, asetilKoA masuk ke dalam siklus asam sitrat untuk kemudian diubah menjadi karbon dioksida (CO2), ATP, NADH dan FADH melalui tahapan reaksi yang kompleks. ${ }^{11,24}$ Setelah melewati berbagai tahapan reaksi di dalam siklus asam sitrat, metabolisme energi dari glukosa kemudian akan dilanjutkan melalui proses fosforilasi oksidatif. Pada proses ini, molekul NADH dan FADH yang dihasilkan pada siklus asam sitrat akan diubah menjadi molekul ATP dan $\mathrm{H}_{2} \mathrm{O}$. Satu buah molekul NADH akan menghasilkan 3 buah molekul ATP dan 1 buah molekul FADH akan menghasilkan 2 molekul ATP. Proses metabolisme energi secara aerobik ini secara keseluruhan akan menghasilkan 38 buh molekul ATP dan produk samping berupa karbon dioksida $\left(\mathrm{CO}_{2}\right)$ serta air $\left(\mathrm{H}_{2} \mathrm{O}\right)$.

Pemenuhan karbohidrat bagi atlet bertujuan untuk mengisi kontraksi otot. Diet tinggi karbohidrat atau penyimpanan glikogen dapat membantu atlet dalam memaksimalkan penyimpanna glikogen dan menjaga daya tahan aerobik saat pertandingan atau latihan. ${ }^{25}$ Buah jeruk juga mengandung karbohidrat yang dapat digunakan sebagai sumber energi untuk atlet dalam melakukan olahraga. Kandungan karbohidrat pada buah jeruk ada dua macam, yaitu karbohidrat sederhana berupa fruktosa, sukrosa dan glukosa serta karbohidrat kompleks berupa polisakarida non pati (serat pangan). Pada penelitian ini, rerata nilai VO2max pada kelompok perlakuan

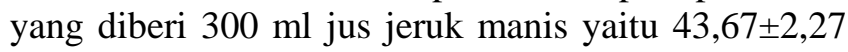
dan pada kelompok kontrol yang diberi $300 \mathrm{ml}$ placebo yaitu 39,33 $\pm 4,39$. Berdasarkan hasil tersebut menunjukkan bahwa rerata nilai VO2max pada kelompok perlakuan yang diberi $300 \mathrm{ml}$ jus jeruk manis (54,9 gram karbohidrat) lebih tinggi secara signifikan $(\mathrm{p}<0,05)$ dibandingkan dengan kelompok kontrol yang tidak diberikan jus jeruk manis (placebo). Hal tersebut sesuai dengan penelitian sebelumnya bahwa jumlah karbohidrat yang diperlukan untuk meningkatkan ketahanan yaitu sebesar 30-60 gram/jam. Jumlah tersebut dapat mempertahankan level glukosa dan menjaga tingkat pembakaran karbohidrat di dalam tubuh, sehingga dapat meningkatkan ketahanan sekitar 30-60 menit. ${ }^{8}$ Pada penelitian lainnya yang menggunakan pisang raja sebanyak 150 gram $(47,7$ gram karbohidrat) dan 300 gram $(95,4$ gram karbohidrat) untuk mencegah kelelahan otot aerob pada atlet sepak takraw menunjukkan perbedaan rerata nilai $\mathrm{VO}_{2}$ max yang signifikan antara kelompok perlakuan dengan kelompok kontrol. ${ }^{6}$

Buah jeruk juga mengandung mineral yang tinggi yaitu kalium. Kalium merupakan mineral utama yang sangat dibutuhkan pada latihan yang membutuhkan daya tahan kuat (endurance). Kalium berperan dalam metabolisme karbohidrat untuk mengubah glukosa menjadi glikogen yang disimpan dalam hati untuk energi.

Kalium merupakan mineral yang penting untuk membentuk otot. Kalium dan natrium berperan dalam kelelahan otot. $\mathrm{K}^{+}$dan $\mathrm{Na}^{+}$dibutuhkan dalam depolarisasi membran sel otot. ${ }^{13}$ Membran gradien ion dapat melintasi membran membutuhkan pompa aktif ion dan energi dalam polarisasi, seperti neuron. Neuron membuat membran sel otot menjadi kebal terhadap $\mathrm{Na}^{+}$, sedangkan ion $\mathrm{Na}^{+}$secara aktif dipompa keluar sel dan ion $\mathrm{K}^{+}$masuk ke dalam sel. Beberapa ion $\mathrm{K}^{+}$ berdifusi kembali keluar namun dengan tingkat yang lebih lambat dibangdingkan $\mathrm{Na}^{+}$yang dipompa keluar. Gradien ion ini bersama anion dari senyawa organik dan protein di dalam sel menyebabkan tegangan saat melintasi membran sel. Ketika membran distimulasi menyebabkan membran menjadi permeabel terhadap natrium dan tegangan yang terjadi akan menurun, sehingga terjadi depolarisasi pada membran. Depolarisasi akan berpindah ke otot melalui tabung melintang, yang menyebabkan pelepasan $\mathrm{Ca}^{2+}$ dan selanjutnya terjadi kontraksi otot. ${ }^{13}$ Apabila terjadi gangguan keseimbangan $\mathrm{K}^{+}$dan $\mathrm{Na}^{+}$akan mempengaruhi depolarisasi membran sel otot. Hal tersebut akan menyebabkan gangguan aktivitas $\mathrm{Ca}^{+}$ dan gangguan suplai energi. Hal tersebut menyebabkan gangguan interaksi antara aktin dan miosin pada otot sehingga mempengaruhi kekuatan otot yang dihasilkan. ${ }^{21}$

Selain itu, kalium juga berfungsi untuk menjaga keseimbangan asam dan cairan pada saat melakukan olahraga. Selama berolahraga, tubuh akan beradaptasi dengan panas yang menyebabkan peningkatan sekresi hormon aldosteron. Hal tersebut menyebabkan atlet akan kehilangan kalium melalui pengeluaran keringat dan urin. ${ }^{26}$ Selain itu, kalium juga merupakan elektrolit yang penting bagi tubuh karena berfungsi dalam mengubah impuls saraf ke otot pada kontraksi otot dan menjaga tekanan darah tetap normal. ${ }^{14}$ Selama berolahraga, kalium dapat diperoleh dari makanan olahraga, seperti mengonsumsi pisang dan jeruk.

Pengaturan makan pada atlet sebelum, selama dan sesudah pertandingan perlu diperhatikan untuk mengurangi risiko kelelahan dan menjaga ketahanan fisik pada atlet. ${ }^{27}$ Mengonsumsi makanan yang mengandung karbohidrat secara adekuat selama olahraga membantu menyediakan glukosa sebagai sumber energi, serta menghemat penggunaan cadangan glikogen otot. Hal tersebut dapat mencegah resiko hipoglikemia. Hipoglikemia dapat menimbulkan kelelahan karena terbatasnya oksidasi glukosa darah. ${ }^{28}$ Mengonsumsi makanan dalam bentuk cair seperti jus jeruk manis menyebabkan zat-zat gizi mudah dicerna oleh lambung dan saluran pencernaan sehingga cepat terserap oleh tubuh dan digunakan sebagai energi. ${ }^{29}$ 
Selain itu, mengonsumsi jus buah yang encer seperti jus jeruk manis akan membantu menjaga level hidrasi tetap baik, menambah simpanan energi, mencegah terjadinya hipolikemia serta menjaga performa tubuh saat olahraga sehingga dapat mengurangi risiko kelalahan otot. ${ }^{30}$

\section{KETERBATASAN PENELITIAN}

Keterbatasan dalam penelitian ini adalah tidak dilakukan pengukuran $\mathrm{VO}_{2} \max$ sebelum intervensi, sehingga tidak dapat melihat nilai $\mathrm{VO}_{2}$ max awal pada kedua kelompok. Selain itu, pada penelitian ini tidak dapat mengontrol aktivitas fisik subjek sehingga tidak diketahui kondisi fisik subjek saat dilakukan tes.

\section{SIMPULAN}

Terdapat perbedaan rerata nilai $\mathrm{VO}_{2} \max$ yang signifikan pada kelompok kontrol dan kelompok perlakuan. Pemberian jus jeruk manis 30 menit sebelum latihan sebanyak $300 \mathrm{ml}$ berpengaruh secara bermakna untuk meningkatkan daya tahan aerob.

\section{SARAN}

1. Perlu dilakukan pengukuran $\mathrm{VO}_{2}$ max sebelum diberikan intervensi sehingga dapat diketahui nilai $\mathrm{VO}_{2}$ max awal pada kedua kelompok.

2. Alternatif lain minuman berkarbohidrat yang dapat dikonsumi oleh atlet selain jus jeruk adalah larutan gula karena cara pembuatannya lebih mudah dan lebih ekonomis. Rekomendasi yang diberikan untuk olahraga dengan durasi lebih dari 60 menit adalah 8 gram $/ 100 \mathrm{ml}$ air.

3. Tiga puluh menit sebelum berolahraga atlet dianjurkan untuk mengonsumsi buah-buahan sebagai sumber karbohidrat dan kalium

\section{UCAPAN TERIMAKASIH}

Puji syukur penulis panjatkan kepada Allah SWT atas limpahan rahmat-Nya kepada penulis. Penulis berterima kasih kepada subjek penelitian, pengurus, serta pelatih sepak bola di Gendut Dony Training Camp (GDTC) Salatiga yang telah bekerjasama dan membantu penulis dalam pelaksanaan penelitian ini.

\section{DAFTAR PUSTAKA}

1. Sukadiyanto. 2005. Penghantar Teori dan Metodelogi Melatih Fisik. Yogyakarta: PKO-FIKUNY. p. 40-68.
2. Sajoto. Peningkatan dan Pembinaan Kekuatan Kondisi Fisik Dalam Olahraga. Jakarta: Effar dan Dhaid Prize: 1988.

3. Maqsalmina M. Pengaruh Latihan Aerobik terhadap Perubahan VO2max pada Siswa Sekolah Sepak Bola Tugu Muda Semarang Usia 12-14 Tahun (Skripsi). Semarang: Universitas Diponegoro; 2007.

4. Cabrera M-CG, Domenech E, Romagnoli M, et al. Oral administration of vitamin $C$ decreases muscle mitochondrial biogenesis and hampers traininginduced adaptations in endurance. The American Journal of Clinical Nutrition. 2008; 87: 142-149.

5. Cynthia. Pengaruh Pemberian Suplemen Besi terhadap Kelelahan Otot. Karya Tulis Ilmiah. Semarang: Fakultas Kedokteran Universitas Diponegoro; 2010.

6. Cicipi Rozana. Pengaruh pemberian pisang (Musa paradisiaca) terhadap Kelelahan Otot Aerob pada Atlet Sepak Takraw. Semarang: Fakultas Kedokteran Universitas Diponegoro; 2014

7. Iwan B. Perbandingan Tes Lari 15 menit Balke dengan Tes Ergometer Sepeda Astrand. JKM. Vol. 7, No.1, Juli 2007: 91 - 94

8. Irawan,MA. Metab olahraga. Polton Sport Science and Performance Lab. Sport Science and Brief Volume 01 (2007) No.04

9. Aditya C, Gusbakti R, Yetty M. Pengaruh latihan aerobik intensitas ringan dan sedang terhadap kelelahan otot (muscle fatigue) atlet sepak bola Aceh. Jurnal Kedokteran Dan Kesehatan, Volume 3, No. 1, Januari 2016: 333-339

10. Aryati, Tjaronosari, dan Nur H. Pengaruh Asupan Karbohidrat Pada Periode Latihan Terhadap Kebugaran Atlet Sepak bola di Klub PSS (PerserikatanSepak Bola Sleman). Yogyakarta : Nutrisia;2004:55-60)

11. Mahan LK, Sylvia Escott-Stump. Krause's Food, Nutrition, and Diet Therapy. 13th ed. Philadelphia: Saunders; 2012. p507 - 521

12. Whitney, Ellie., Rolfes, Sharon R. Understanding Nutrition, Eleventh Edition. Belmont: Thomson Wadworth;2008.

13. Hana R. Pohl , John S. Wheeler, and H. Edward Murray. Sodium and Potassium in Health and Disease. 2013

14. Whitney, E. \& Rolfes, S. 1999. Understanding nutrition. Belmont, Ca., USA, West/Wadsworth. Eighth ed. (ed. W. Rolfes)

15. Heater HF, Lisa AB, Alan EM. Practical application in sports nutrition. 3rd ed. United States of America: Jones and Bartlett Publisher; 2006.

16. Katrine B. The Health Benefits of Citrus Fruits. Horticulture Australia: CSIRO Health Science \& Nutrition; 2003. 
17. Teresa Cutter. Sports Recovery Smoothies. [online]. [cited 2016 May 22]. Available from: http://www.thehealthychef.com

18. USDA National Nutrient Database for Standard Reference, Release 17 Potassium, K (mg) Content of Selected Foods per Common Measure. Available from: http://www.nal.usda.gov/fnic/foodcomp/Data/SR 17/wtrank/sr17a306.pdf; accessed 20 Sept 2016

19. Christine, Economos dan W D, Clay. Nutritional and health benefits of citrus fruits. FNA/ANA 24, 1999.

20. Sutopo. Teknik Budidaya Jeruk Manis Pacitan. [online]. 2015 [cited: 2016 Juni 1]. Available from: http://balitjestro.litbang.pertanian.go.id/teknikbudidaya-jeruk-manis-pacitan/

21. William, Craig A, Sebastian R, editors. Human Muscle Fatigue. NY:Routledge. 2009; p20-40

22. Agung, Septian Nosa. Survei Tingkat Kebugaran Jasmani Pada Pemain Persatuan Sepakbola Indonesia Lumajang. Semarang : Program Studi Pendidikan Kepelatihan Olahraga Universitas Negeri Semrang; 2015.

23. Putra, Yan Syantica. Perbedaan Tes Balke, Tes Cooper, dan Tes Multistage Terhadap Daya Tahan Aerobik Atlet Bola Voli Yuso Sleman.Yogyakarta: Program Studi Pendidikan Kepelatihan Olahraga Universitas Negeri Yogyakarta;2013.

24. Bender DA, Peter AM. Glikolisis dan Oksidasi Piruvat. In: Murray RK, Daryl KG, Victor WR, editors. Biokimia Harper. 27th ed. Jakarta : EGC;2009. p158 - 16

25. Gee M., Mahan LK and Escott-Stump S., 2008. Weight management. In: Mahan LK, EscottStump S., eds. Krause's Food \& Nutrition Therapy. 12th ed. St. Louis: Saunders Elsevier, 532-562.

26. Guyton AC, Hall JE. Buku ajar fisiologi kedokteran edisi 11. Jakarta: EGC; 2007.hal.81$85 ; 874-880$

27. Kementrian Kesehatan RI. Pedoman Gizi Olahraga Prestasi. 2013. Hal 30

28. Willam MH. Nutrition for health, finess, and sport. 8th edition. New York: Mc graw-Hiil Companies, inc; 2007.p.118-20; 122; 124; 125; $128 ; 129 ; 131$.

29. Wirakusumah, Emma S. Jus sehat buah dan sayuran. Jakarta: Penebar Swadaya; 2013

30. Djoko Pekik Irianto. Panduan Gizi Lengkap Keluarga dan Olahragawan. Yogyakarta: Penerbit Abadi. 2006. 